\title{
EXAMPLE OF GOOD PRACTICE IN SUPPORT EDUCATION OF CNC MACHINE PROGRAMMING AT TECHNICAL UNIVERSITY
}

Naděžda ČUBOŇOVA, Žilinská univerzita v Žilině, Slovenská republika Nataša NÁPRSTKOVA*, Univerzita Jana Evangelisty Purkyně v Ústí nad Labem, Česká republika

Přijato: 18. 5. 2018 / Akceptováno: 9. 8. 2018

Typ článku: Teoretická studie

DOI: $10.5507 /$ jtie.2018.005

Abstract: The article highlights the good practice of teaching CNC machine programming at a particular university where, as presented, it was necessary to create suitable conditions for this teaching because the use of CNC technology in current technical practice is one of the important areas where a graduate of a technical university can apply. Presented example can be seen as a recommendation for other universities, which also deal with this issue, how to design similar lessons, what elements can be used, how to engage e-technology in teaching. There are described the possibilities of the process of creating a system and its involvement for teaching of CNC programming, which, as mentioned above, is an important part of current production processes.

Key words: CNC programing, software, teaching, practice.

\section{PŘÍKLAD DOBRÉ PRAXE PRO PODPORU VÝUKY PROGRAMOVÁNÍ CNC STROJŮ NA VŠ}

Abstrakt: Článek poukazuje na ukázku dobré praxe výuky programování CNC strojů na konkrétni $V S ̌$, kdy, jak je prezentováno, bylo nutné vytvořit vhodné podminky pro tuto výuku, protože využiti CNC techniky v současné technické praxi je jednou z důležitých oblastí, kde se müže absolvent technické VŠ uplatnit. Uvedený př́klad je možné vnímat jako doporučení pro jiné VŠ, které se uvedenou problematikou rovněž zabývaji, jak podobnou výuku koncipovat, jaké prvky je možné použit, jak do výuky zapojit IT technologie. Jsou zde popsány možnosti postupu při tvorbě systému pro výuku a jeho zapojení do výuky CNC programování, které je, důležitou součástí současných výrobních postupů.

Klíčová slova: CNC programování, software, výuka, praxe.

*Autor pro korespondenci: natasa.naprstkova@ujep.cz 


\section{1 Úvod}

V současnosti je vzdělání samozřejmou nutností, ale současně také konkurenční výhodou. Průmyslové výroby se to týká zcela jednoznačně. Pro tuto situaci by měly být také přizpůsobeny vzdělávací postupy, a to nejen na vysokých školách technického směru, ale také $\mathrm{v}$ podnikové praxi. Oblast $\mathrm{CNC}$ programování je jednou z důležitých částí průmyslové výroby, a proto i této problematice je nutné věnovat pozornost. (Kuśmierczak, 2015; Náprstková 1, 2011)

Rozvoj internetových platforem a elektroniky dává další možnost, jak přiblížit problematiku programování CNC strojů studentům a jak zvýšit a zefektivnit kvalitu výuky v této oblasti. Potřeba šiřrení informací do světa elektronických vzdělávacích systémů přináší v současnosti stále nové poznatky, nástroje a programy pro tvorbu takovýchto vzdělávacích prostředků, které rozšiřují a vylepšují možnosti zpracování potřebných informací. Počítačové systémy a jejich propojení dovolují aktívnější přenášení informací a tím poskytují také (a významně) zdroje dalšího vzdělávání. Vývoj nových informačních technologií umožňuje nový přístup $\mathrm{k}$ uložení a výběru informací a $\mathrm{k}$ využití možností e-vzdělávání. Informační technologie označované také jako e-technologie (využívané v elektronickém vzdělávání) jsou založeny na principu šíření informací internetem, časově neomezeném přístupu $\mathrm{k}$ informacím, na cíleném zaměření vzdělávacích modulů a interaktivním přistupu k daným informacím. (Ťavodová, 2010; Šugárová \& Šugár, 2009)

Jak již bylo výše zmíněno, platí to samozřejmě také v oblasti výuky programování CNC výrobní techniky, potažmo obráběcích strojů. Znalosti v této oblasti mohou studentům velmi pomoci, zejména $\mathrm{v}$ uplatnění na trhu práce, kdy je $\mathrm{v}$ této oblasti po pracovnících ovládajících tyto znalosti velká poptávka. Toto je samozřejmě způsobeno současným vývojem v oblasti průmyslové výroby. (Náprstková, 2009; Náprstková 1, 2010)

$\mathrm{Z}$ těchto důvodů je nutné věnovat pozornost způsobům výuky v této oblasti a zapojit do ní současné možnosti a moderní technologie, zejména v oblasti počítačové podpory. Článek popisuje jeden prŕíklad takového řešení, tedy př́iklad dobré praxe, jak je možné k výuce CNC programování přistupovat a jak je možné řešit její naplnění a př́ípadně zvýšit atraktivitu probírané látky pro studenty.

Jedná se zde tedy o aplikaci informačních technologií pro výuku CNC programování. Takovým řešením může být např. vytvoření portálu pro komplexnější přístup výuky programování CNC strojů (CNC výrobní techniky). (Čuboňová \& Náprstková, 2013; Mečiarová, 2009) Zde je uveden konkrétní příklad dobré praxe, kdy vyhovující systém pro takto pojatou výuku byl vytvořen na Katedře automatizace a výrobních systémů Fakulty strojní Žilinské univerzity v Žilině.

Podnětem pro tvorbu systému byla rozvíjející se oblast CNC výrobní techniky (strojů), programování CNC strojů, dílenského programování atd., na které je nutno neustále reagovat. Cílem prezentovaného řešení bylo vytvořit pro studenty hlavně komplexní interaktivní edukační portál, který by jim co možná nejvíce umožnil využívat moderní a současné prostředky informačních a internetových technologií.

Koncepční návrh řešení portálu vyplynul zároveň z dlouhodobé spolupráce zmíněného pracoviště se strojírenskou praxí, z aktuálních požadavků na školení pracovníků z praxe a také $\mathrm{z}$ různých řešení konkrétních úloh $\mathrm{z}$ praxe $\mathrm{v}$ rámci závěrečných prací studentů. Hlavním cílem prezentovaného řešení byla implementace informačních technologií do vzdělávacího procesu v oblasti programování CNC strojů. (Čuboňová, 2002; Čuboňová \& Kuric, 2009; Náprstková \& Náprstek, 2010) 
Článek popisuje možnosti vývoje komplexního interaktivního edukačního portálu pro podporu výuky programování CNC strojů na konkrétní VŠ.

\section{Analýza možností vytvoření systému pro výuku CNC programování}

Pro realizaci výše zmíněného řešení bylo nutné analyzovat a připravit kroky postupu pro tvorbu edukačního portálu. Na zde prezentované body lze pohlížet jako na postup vhodný $\mathrm{i}$ pro jiné vysoké školy a vzdělávací pracoviště v daném oboru.

Nejprve je vždy nutné analyzovat a specifikovat aktuální stav již existujících učebních textů, didaktických pomůcek, multimediálních programů, hypertextových elektronických publikací, web aplikací využívaných na daném pracovišti v oblasti programování CNC strojů atp. (Čuboňová \& Kuric, 2009; Náprstková \& Náprstek, 2010)

Dále je nutné vytipovat nové tematické okruhy v závislosti na doplnění již existujících výrobních zařízení na pracovišti, což je vždy závislé na konkrétních podmínkách toho kterého pracoviště (např. na výše zmíněném pracovišti je k dispozici ř́zení EMCO, a zde se jednalo o to, zda toto řízení je možné doplnit dalšími možnostmi řízení, tj. implementováním dalších řídicích systémů, např. HEIDENHAIN, FANUC či FAGOR resp. EMCOTRONIC). (Náprstková 2, 2010; Náprstková 2, 2011)

Je nutné také navrhnout, které nové učební texty, didaktické pomůcky, elektronické publikace a webové aplikace, resp. edukační programy, bude nutné vytvořit pro potřeby rozšíření a aktualizace dané problematiky o nové tematické okruhy. U prezentovaného pracoviště se jednalo hlavně o oblasti:

- programování CNC výrobních strojů daného typu (např. na výše zmíněném pracovišti se jednalo o stroje EMCO a o možnosti programování nově vytipovaných řídicích systémů HEIDENHAIN, FANUC či FAGOR resp. EMCOTRONIC,

- použití dílenského programování (bud' nový upgrade již existujícího řídícího software stávajících strojů (ve výše zmíněném konkrétním př́ípadě se jednalo o stroj EMCO s ř́́dicím systémem Sinumerik 840D na Sinumerik Operate) nebo zcela nově zavést problematiku dílenského programování),

- použití programování $\mathrm{s}$ využitím $\mathrm{CAD} / \mathrm{CAM}$ systémů, a to i v oblasti postprocesingu (ve výše popisovaném př́padě se jednalo o postprocessing v CAM systému EdgeCAM pro CNC stroje EMCO.

Důležitým krokem řešení je také si promyslet a př́padně navrhnout (je-li to možné) vybudování či dobudování specializovaného školícího pracoviště pro programování CNC strojů (ve výše zmíněném konkrétním př́ípadě se jednalo o návrh výukové laboratoře na bázi strojů EMCO rozšířené o implementaci nových řídicích systémů HEIDENHAIN, FANUK či FAGOR resp. EMCOTRONIC a upgrade řídícího software Sinumerik Operate). (Čuboňová, 2013)

Dále je nutné navrhnout koncepci tvorby, struktury a jednotlivých celků komplexního interaktivního edukačního portálu pro podporu výuky programování CNC strojů (učebních textů, didaktických pomůcek, elektronických publikací, web aplikací atp.).

Důležitým dalším krokem je naplánovat začlenění a ověření následně vytvořených programových softwarových řešení do edukačního portálu, kde studenti pak budou mít možnost interaktivního př́istupu k uloženým edukačním materiálům.

Také je dobré promyslet zpracování vybraných edukačních programů $\mathrm{v}$ cizím (nejčastěji anglickém) jazyce, zejména v souvislosti s programy ERASMUS+ či CEEPUS, kdy př́slušnou instituci navštíví zahraniční studenti, kteří tuto př́ležitost mohou využít. 
V rámci spolupráce s jinými VŠ pracovišti je také dobré konzultovat zpř́stupnění portálu i mimo řešitelské pracoviště.

\section{Materiálové zabezpečení pro vytvoření konkrétního systému pro výuku programování CNC strojů}

Ve zde prezentovaném př́ikladu dobré praxe, který řeší inovaci v rámci výuky $\mathrm{CNC}$ programování na daném pracovišti, byly realizovány kroky, které vycházely z metodiky v kapitole 2. Pro takovou inovaci jsou vždy limitujícím prvkem finanční a prostorové prostř̌edky a pracoviště, které se tímto problémem zabývá, musí vycházet ze svých možností. Zde jsou uvedeny konkrétní inovace, které byly v rámci tvorby výukového systému realizovány. Jednalo se o nákup důležitých položek, které byly nezbytné pro realizaci prezentovaného výukového systému.

Prezentované pracoviště bylo již na počátku vybaveno CNC stroji EMCO (školní soustruh a školní frézka). Po konzultacích byl v rámci inovací výuky zakoupen nový rídicí systém HEIDENHAIN TNC426/430 pro frézku EMCO Concept Mill 105 (ř́́dicí systém pro soustruh se $\mathrm{z}$ finančních důvodů nerozšiřoval) a multilicence tohoto systému (software) pro PC. Řešení inovací ve výuce bylo směřováno $\mathrm{k}$ vypracování webové aplikace pro podporu výuky programování pro daný rídicí systém. Dále do nově budovaného systému výuky byly samozřejmě zahrnuty také aktualizace obsahu již existujících webových aplikací pro ř́idicí systém Sinumerik 840D a řídící software EMCO WinNC a jejich implementace do vytvářeného výukového portálu pro oba stroje, tedy frézku i soustruh EMCO.

Dílenské programování je v současnosti ve strojní výrobě často využíváno, a proto je nutné na něj pamatovat i v rámci výuky $\mathrm{CNC}$ programování. $\mathrm{V}$ prezentovaném systému v oblasti dílenského programování tedy došlo $\mathrm{k}$ zakoupení upgrade ř́íícího software Sinumerik 840D na Sinumerik Operate, který výuku dílenského programování dovoluje, a to na stávajícím vybavení, které má prezentované pracoviště k dispozici (frézka EMCO Concept Mill, soustruh EMCO Concept Turn). Webová aplikace pro výuku CNC programování byla tedy rozšířena i o tuto oblast.

Také byl v rámci realizace výukového systému zakoupen upgrade $\mathrm{CAD} / \mathrm{CAM}$ systému Edgecam pro výuku automatizovaného způsobu programování CNC výrobních strojů. Tento software dovoluje také tvořit postprocesory a byl proto využit pro realizaci postprocesoru pro nově zakoupený ř́́dicí systém HEIDENHAIN TNC426/430.

Protože konkrétní pracoviště je vybaveno také 3D tiskárnou Easy 3D Maker, v realizovaném výukovém portálu byla vytvořena i kapitola zpracovávající tuto problematiku.

\section{Postup při tvorbě prezentovaného systému pro výuku programování CNC strojů}

Úkony prezentované v kapitole 3 představují vybavení, která byla $\mathrm{k}$ dispozici, či která byla nově pořízena a lze je brát jako př́klad možností, jak podobný výukový systém realizovat i na jiném pracovišti.

Postup práce při samotné realizaci výukového portálu je shrnut $\mathrm{v}$ následujících odstavcích a prezentované informace lze brát jako př́klad dobré praxe, jak podobnou situaci řešit i na jiném VŠ pracovišti.

Pro realizaci portálu bylo nutné shromáždit podklady pro zpracování vytipovaných tematických okruhů řešení do elektronické podoby. Konkrétně se jednalo o vypracování dokumentačních podkladů pro tvorbu nové webové aplikace, s jejiž pomocí je možné 
ovládat řídicí systém HEIDENHAIN TNC426/430 pro frézku EMCO Concept Mill (obr. č. 1, ilustrační obrázek web aplikace). Dále bylo nutno popsat stávající obsah existujících webových aplikací pro řídicí systém Sinumerik 840D a řídící software EMCO WinNC. V rámci tohoto popisu byly navrženy všechny změny pro doplnění a úpravu již dřive vytvořených aplikací a jejich začlenění do nového výukového systému.
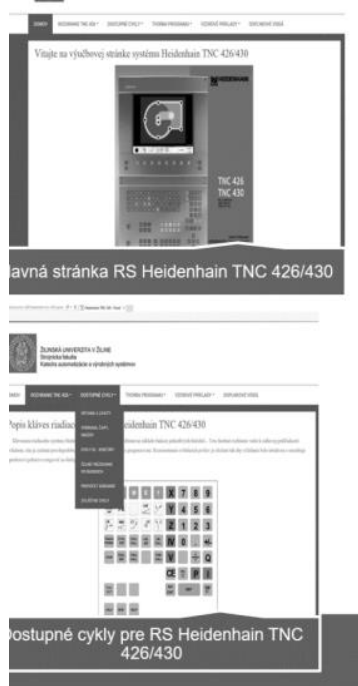

Obr. c. 1: Web aplikace (interface) pro programování ř́dicího systému HEIDENHAIN TNC426/430

Pro oblast dílenského programování byly vypracovány textové elektronické podklady nutné pro tvorbu a naplnění nové webové aplikace pro soustruh a frézku EMCO s novým řídicím systémem Sinumerik Operate (obr. č. 2, ilustrační obrázek web aplikace). Dále byla zpracovaná dokumentace pro vytvoření již zmíněného postprocesoru.

Pro oblast rapid prototypingu byly také vypracovány podklady pro vytvoření webové aplikace, s jejiž pomocí je možné ovládat 3D tiskárnu Easy 3D Maker (obr. č. 3, ilustrační obrázek web designu).

Bylo nutné zrealizovat analýzu využití podobných, již vytvořených, internetových edukačních stránek a portálů a následně byl zpracován návrh informační struktury nového portálu a byla vytvořena metodika pro řešení dílčích úloh (jednotlivých webových aplikací) pro výsledný edukační portál. Dále byl vyspecifikován rozsah a náplň jednotlivých celků portálu s využitím aktualizovaných a nových elektronických učebních textů.

Dále byly zvoleny programové nástroje pro tvorbu jednotlivých webových aplikací a samotného edukačního portálu, $v$ tomto př́padě byl použit redakční systém Joomla, pro textové a prezentační soubory byly využity nástroje MS Office Power Point, Excel, Word, Adobe Acrobat Pro a software Camtasia jako nástroj pro záznam a zpracování obrazu. 

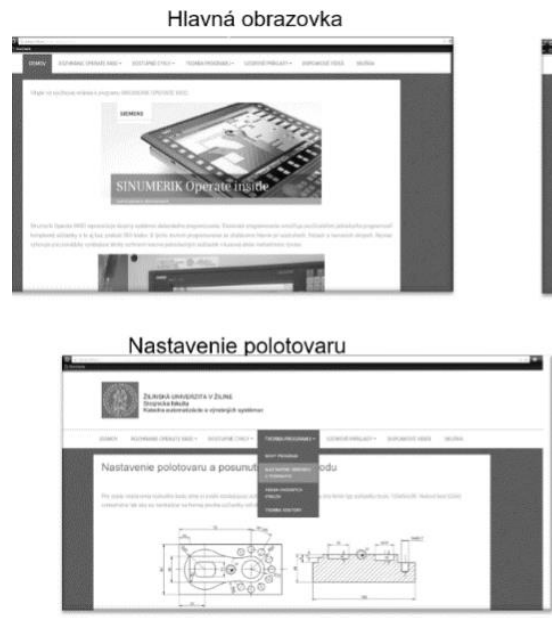

Dostupné cykly

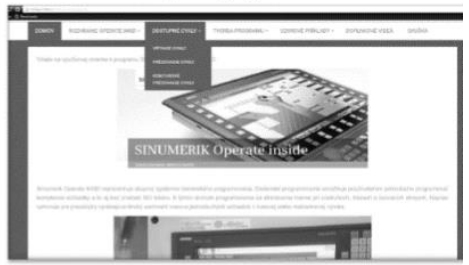

Animačné prvky aplikácie

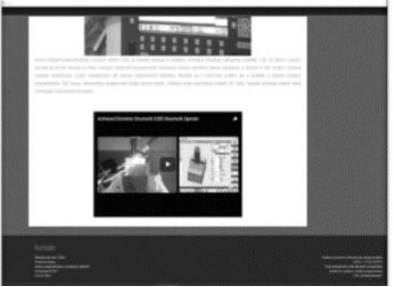

Obr. č. 2: Hlavni pohled na menu v uživatelské aplikaci pro programováni EMCO WinNC Sinumerik Operate

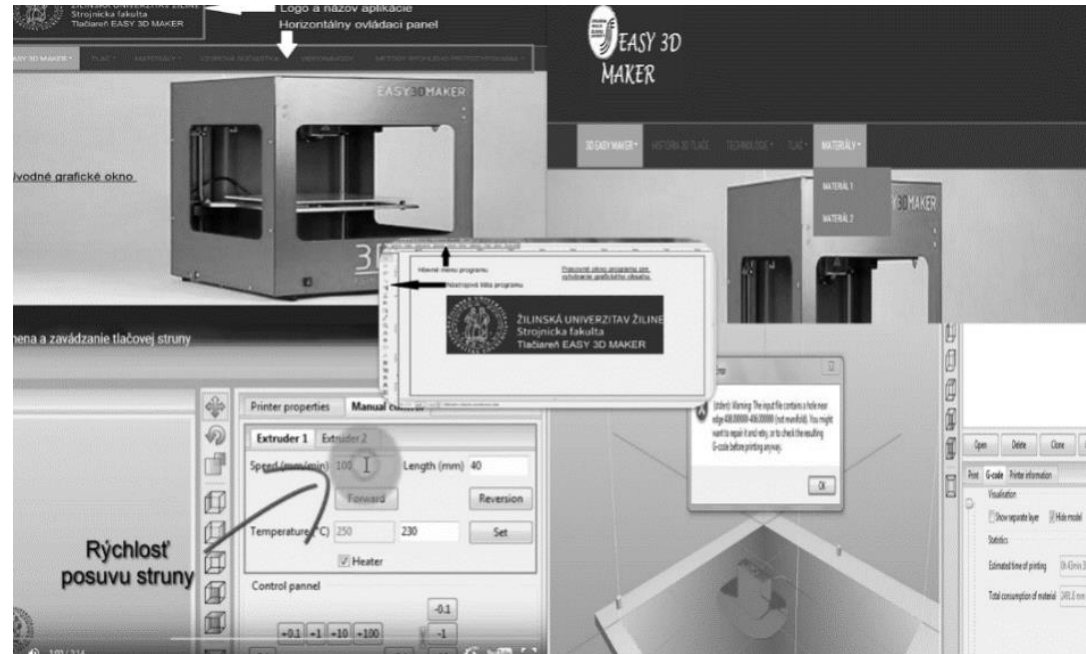

Obr. č. 3: Webová aplikace pro řizení 3D tiskárny Easy 3D Maker

Pro př́ípadné zahraniční studenty byly zpracovány studijní podklady v angličtině. Jednalo se o interní učební texty s názvem „CNC machine programming“ a „Computer Aided Manufacturing“ (obr. č. 4, ilustrační obrázek web aplikace). Dále v edukačním systému byla zpracována webová aplikace „EMCO training program“ pro výuku řídicího systému Sinumerik 840D a software WinNC. 


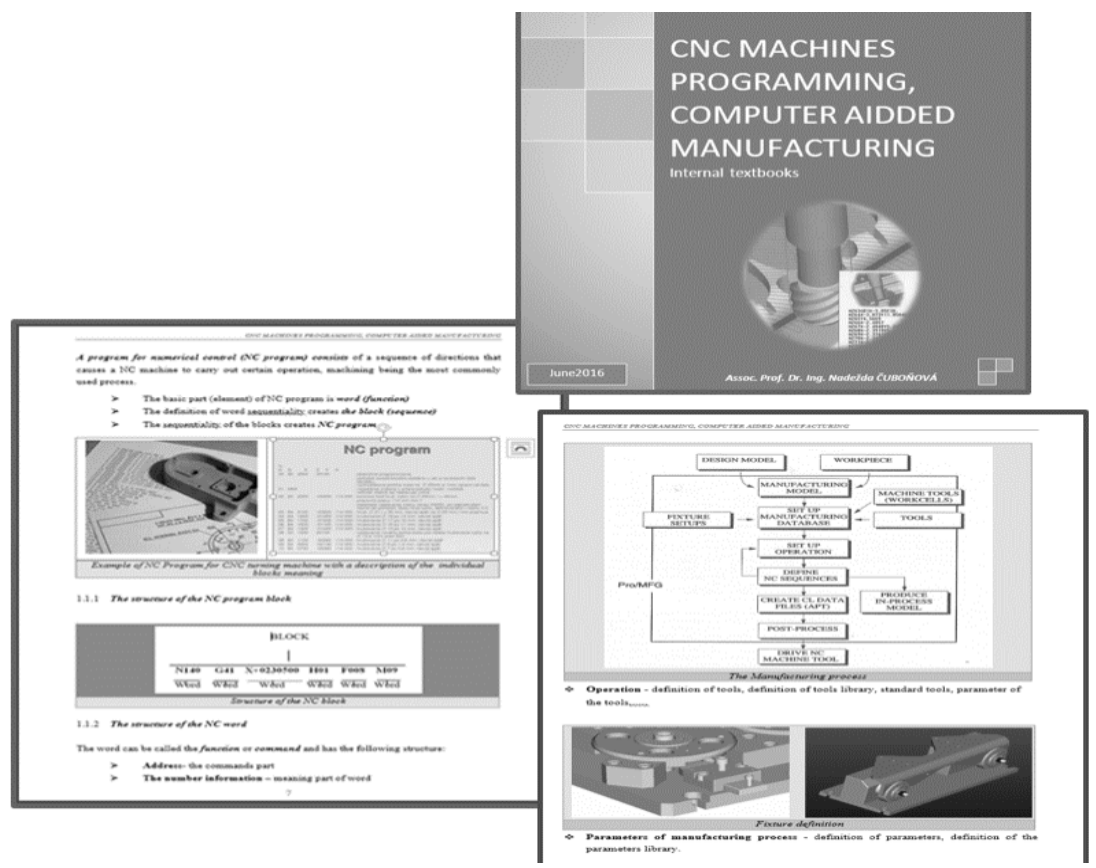

Obr. č. 4: Upravený výukový text pro zahraniční studenty

Veškeré výše zmíněné aktivity vedly $\mathrm{k}$ inovaci výuky CNC programování v rámci již existující laboratoře CNC programování, kterou je možné nalézt $\mathrm{v}$ prostorách výše zmíněného pracoviště. Zároveň možnosti této laboratoře byly doplněny možností umístit edukační materiály a interaktivní aplikace na internet a tam je zpř́istupnit pro studenty.

Laboratoř (obr. č. 5) je tedy vybavena výukovými CNC stroji EMCO Concept Turn 55 (obr. č. 6) a EMCO Concept Mill 105 (obr. č. 7). Oba stroje jsou řízeny prostrednictvím PC. Na obou strojích je nyní možné použít další řídicí systémy. Výměna řídicího systému probíhá prostřednictvím spuštění příslušného software pro daný řídicí systém a výměnou řídících panelů, které náležejí danému typu řídicího systému. Čas výměny řídících panelů je řádově několik minut. Př́íprava řídícího programu, formát zápisu, použité funkce atd., se samozřejmě pro jednotlivé řídicí systémy liší. Pro komplexnost výuky programování $\mathrm{CNC}$ strojů je proto důležité studentům přiblížit různé zpo̊soby př́ípravy $\mathrm{NC}$ programu pro CNC stroje. Laboratoř programování $\mathrm{CNC}$ strojů byla před prezentovanou modernizací vybavena, kromě CNC frézky a soustruhu, také deseti PC s ovládacími panely Sinumerik 840D a řídícím software Emco WinNC. Nově byla laboratoř dovybavena rrídicím systémem HEIDENHAIN TNC426/430 a jeho multilicencí pro 10 PC, čímž se samozřejmě rozšiřila možnost pro studenty seznámit se s dalším způsobem programování CNC strojů, což v současné době přispívá ke zlepšení jejich uplatnění na trhu práce. 


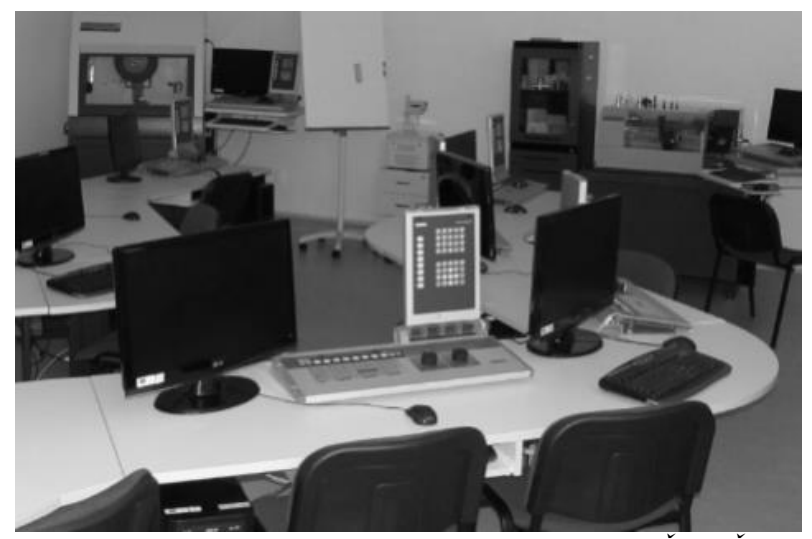

Obr. č. 5: Laboratoŕ programováni CNC strojů na ŽU v Žilině

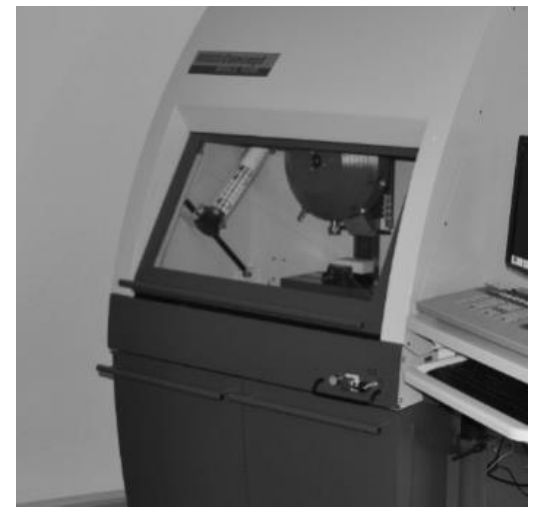

Obr. ̌́. 5: EMCO Concept Mill 105

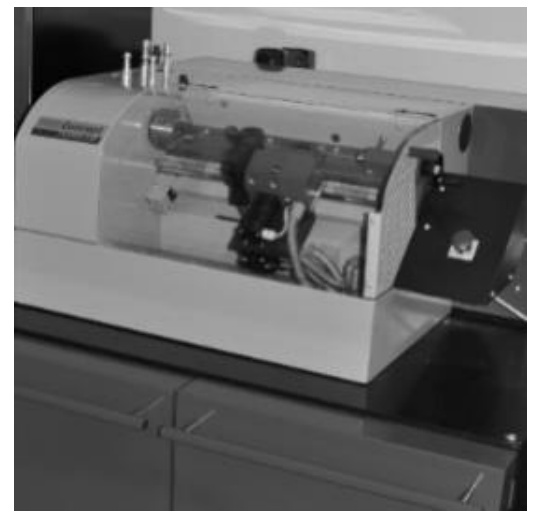

Obr. č. 5:EMCO Concept Turn 55

Také nově pořízený řídicí systém HEIDENHAIN TNC426/430 se stal součástí vyměnitelného ř́ídícího software EMCOWinNC. EMCOWinNC umožňuje studentům naučit se až osm běžně používaných ř́idicích systémů (Sinumerik, Heidenhain, FANUC...) na jednom počítači. Řídicí panel odpovídá obsluze a funkcím řízení stroje a je možné ho použít na běžném PC. Student tak má možnost pracovat na PC jako na stroji a má tak možnost seznámit se detailně se všemi aspekty programování př́slušného ř́zení, což je pro studenty velmi užitečné.

Jak bylo výše řečeno, pro zefektivnění výuky tohoto typu programování byla pro řídicí systém HEIDENHAIN TNC426/430 vytvořena webová aplikace, která obsahovala základní informace o CNC stroji a pracovním prostředí rídícího software. Tato aplikace byla vytvořena pomocí redakčního systému Joomla a byla vytvořena tak, aby ji v budoucnosti bylo možné jednoduchým způsobem doplňovat a upravovat. Tato aplikace doplnila výukové aplikace stávající, a to dvě pro ovládání soustruhu a frézky EMCO a dvě pro ovládání řídícího software EMCO WinNC Sinumerik840D. Všechny aplikace jsou 
koncipovány podobně. První dvě obsahují základní informace týkající se konstrukce, technických a technologických parametrů strojů (ve vizuální či audio podobě), další webové aplikace pro ovládání řídícího software WinNC obsahují informace pro programování CNC soustruhu a frézky EMCO s ř́idicím systémem Sinumerik840D. Všechny aplikace se ovládají přes uživatelské menu a kromě textu a základních informací, týkajících se dané problematiky, obsahují také videoanimace rozšiřující vědomosti potřebné $\mathrm{k}$ ovládání a programování těchto strojů. Následně byly webové aplikace začleněny do obsahu edukačního portálu.

\section{Závěr}

Prezentované řešení je velmi dobrým príkladem dobré praxe $\mathrm{v}$ dané oblasti. Zkvalitňování výuky a zlepšování př́istupnosti vyučované látky pro studenty je důležitým prvkem současného edukačního procesu. Studenti v rámci prezentovaného řešení mají jedinečnou př́ležitost získat zkušenosti s různými systémy programování CNC strojů, což je problematika více než současná a $\mathrm{v}$ průmyslové praxi velmi žádaná. Znalosti v této oblasti jsou pro absolventy technických škol velmi užitečné a zlepšují jim jejich možnosti pro uplatnění na trhu práce. Webové aplikace sloučené do edukačního portálu jsou výborným řešením, jak zlepšit a zpř́stupnit výukové materiály studentům. Studenti dále, díky vybavení laboratoře CNC programování, získají praktické zkušenosti s programováním CNC strojů v oblasti soustružení a frézování, jsou schopni vypracovat CNC program pro konkrétní stroj, seznámí se se způsoby kódování jednotlivých ř́dicích systémů, které jsou v rámci laboratoře $\mathrm{CNC}$ programování $\mathrm{k}$ dispozici.

Tento př́iklad dobré praxe ve výuce CNC programování jako koncept je možné rozhodně doporučit jako inspiraci pro jiná vysokoškolská pracoviště. Pro prezentovaný výukový portál je $\mathrm{v}$ současnosti plánováno, že bude $\mathrm{v}$ budoucnosti zpř́ístupněn pro spolupracující vysokoškolská pracoviště, což dále rozššríi okruh jeho uživatelů.

\section{Literatura}

Čuboňová, N. (2002). The Examples of CAD/CAM Systems Utilization in Mechanical Engineering Industry. International DAAAM Workshop, Cracow, Poland, Cracow Technical University, pp. 10-14.

Čuboňová, N. (2013). Postprocessing of CL Data in CAD/CAM System Edgecam using the Constructor of postprocessors. Manufacturing Technology, Ústí nad Labem, ČR, FSI JEPU, 13(2). pp. 158-164.

Čuboňová, N., Náprstková, N. (2013). Innovation and Supports for Courses Focusing on Teaching of Computer Aided Manufacturing and CAD/CAM System Edgecam. Konference Strategie technického vzdělávání v reflexi doby 2013. Ústí nad Labem, ČR, FVTM UJEP.

Čuboňová, N., Kuric, I. (2009). Využitie multimédií vo výučbe študijného programu „automatizované výrobné systémy“. Sborník Inovatívne postupy vyučby výrobných technológií na univerzitnom stupni štúdia, Zvolen, Slovensko, Technická univerzita vo Zvolene, pp. 11-21.

Kuśmierczak S. (2015). Usage of Technical Equipment in Teaching Technical Subject. International conference Engineering for Rural Development 2015. Jelgava, Latvia, University of Agriculture, pp. 748-752. 
Mečiarová, J. (2009). Využitie CA systémov pri výučbe výrobných technológií. Sborník Inovatívne postupy výučby výrobných technológií na univerzitnom stupni štúdia. Zvolen, Slovensko, Technická univerzita vo Zvolene, pp. 35-39

Náprstková, N. (2009). Zapojení studentů do řešení praktických úloh jako prostředek zvyšováni jejich dovedností. In Proceedings Inovatívne postupy výučby výrobných technológií na univerzitnom stupni štúdia. Zvolen, Slovensko, Technická univerzita vo Zvolene, pp. 51-58.

Náprstková, N. (2010). Zpracování experimentu pro použití studenty. In Proceedings Inovatívne postupy výučby výrobných technológií a materiálov na báze elektronického vzdelávania. Zvolen - EU: TU vo Zvolene, pp. 43-51.

Náprstková, N. (2010). Students connecting to production problems resolutions in $\mathrm{CAD} / \mathrm{CAM}$ area. In International conference. Engineering for Rural Development 2010. Jelgava - EU: University of Agriculture, Faculty of Engineering. pp. 310-314.

Náprstková, N. (2011). Making of experiment for student usage. In International conference Engineering For Rural Development 2011. Jelgava - EU: University of Agriculture, Faculty of Engineering, pp. 558-563.

Nárstková, N. (2011). Using of Catia V5 Software for Teaching at Faculty of Production Technology and Management. In International conference Engineering for Rural Development 2011. Jelgava - EU: University of Agriculture, Faculty of Engineering. p. 554-557.

Náprstková N., Náprstek, V. (2007). Surfcam and its Education at FPTM. In International conference Engineering for Rural Development 2007. Jelgava - EU: University of Agriculture, Faculty of Engineering. pp. 232-235.

Šugárová J., Šugár P. (2009) Nové prístupy k výučbe výrobných technológií. In Inovatívne postupy vyučby výrobných technológií na univerzitnom stupni štúdia. Zvolen - EU: TU vo Zvolene. pp. 73-77.

Ťavodová, M. (2010) Možnosti inovácií výučby strojárskych technológií. In Proceedings Zvyšovanie efektívnosti vzdělávacieho procesu prostredníctvom inovačných prostriedkov. Zvolen - EU: TU vo Zvolene. pp. 81-85.

\section{Poděkování}

Autoři děkují projektům a grantům KEGA No. 037ŽU-4/2014, No. CZ.1.05/4.1.00/11.0260 EDIMARE a SGS FSI UJEP v Ústí nad Labem pro rok 2018, $\mathrm{s}$ jejichž podporou př́íspěvek vznikl. 